\title{
Darcian Natural Convection in an Inclined Trapezoidal Cavity Partly Filled with a Porous Layer and Partly with a Nanofluid Layer
}

(Perolakan Semula Jadi Darcian dalam Rongga Trapezium Condong yang Sebahagiannya Dipenuhi dengan Lapisan Berliang dan Sebahagiannya dengan Lapisan Nanobendalir)

\section{A.I. Alsabery, A.J. ChamkHa, H. SAlEH, I. HASHIM* \& B. CHANANE}

\begin{abstract}
The problem of Darcian natural convection in a trapezoidal cavity partly filled with porous layer and partly with nanofluid layer is studied numerically using finite difference method. The left slopping wall is maintained at a constant hot temperature and the right slopping wall is maintained at a constant cold temperature, while the horizontal walls are adiabatic. Water-based nanofluids with $\mathrm{Ag}$ or $\mathrm{Cu}$ or $\mathrm{TiO}_{2}$ nanoparticles are chosen for the investigation. The governing parameters of this study are the Rayleigh number $\left(10^{4} \leq R a \leq 10^{7}\right)$, Darcy number $\left(10^{-5} \leq \mathrm{Da} \leq 10^{-3}\right)$, nanoparticle volume fraction $(0 \leq \phi \leq 0.2)$, porous layer thickness $(0.3 \leq S \leq 0,7)$, the side wall inclination angle $\left(0^{\circ} \leq \varphi \leq 21.8^{\circ}\right)$ and the inclination angle of the cavity $\left(0^{\circ} \leq \varpi \leq 90^{\circ}\right)$. Explanation for the influence of various above-mentioned parameters on streamlines, isotherms and overall heat transfer is provided on the basis of thermal conductivities of nanoparticles, water and porous medium. It is shown that convection increases remarkably by the addition of silver-water nanofluid and the heat transfer rate is affected by the inclination angle of the cavity variation. The results have possible applications in heat-removal and heat-storage fluid-saturated porous systems.
\end{abstract}

Keywords: Darcy model; nanofluid; natural convection; partially filled; porous media

ABSTRAK

Masalah perolakan semula jadi Darcian dalam rongga trapezium yang sebahagiannya dipenuhi dengan lapisan berliang dan sebahagiannya dengan lapisan nanobendalir dikaji secara berangka menggunakan kaedah perbezaan terhingga. Dinding cerun sebelah kiri dikekalkan pada suhu panas tetap yang berterusan dan dinding cerun kanan dikekalkan pada suhu sejuk berterusan, manakala dinding mendatar secara adiabatik. Nanobendalir berasaskan air dengan zarah nano Ag atau Cu atau TiO telah dipilih untuk kajian. Parameter penentu kajian ini adalah nombor Rayleigh $\left(10^{4} \leq \mathrm{Ra}\right.$ $\left.\leq 10^{7}\right)$, nombor Darcy $\left(10^{-5} \leq \mathrm{Da} \leq 10^{-3}\right)$, pecahan isi padu zarah nano $(0 \leq \phi \leq 0.2)$, ketebalan lapisan berliang $(0.3$ $\leq S \leq 0,7)$, sebelah dinding sudut condong $\left(0^{\circ} \leq \varphi \leq 21.8^{\circ}\right)$ dan sudut condong berongga $\left(0^{\circ} \leq \varpi \leq 90^{\circ}\right)$. Penjelasan untuk pengaruh pelbagai parameter yang tersebut ke atas garis strim, isoterma dan pemindahan haba keseluruhan juga disediakan berdasarkan terma kekonduksian zarah nano, air dan medium berliang. Ia menunjukkan bahawa perolakan meningkat secara luar biasa dengan penambahan nanobendalir air-perak dan kadar pemindahan haba dipengaruhi oleh sudut condong variasi berongga. Keputusan ini mempunyai potensi pengaplikasian dalam sistem pemindahan haba dan penyimpanan haba cecair-tepu berliang.

Kata kunci: Nanobendalir; media berliang; model Darcy; perolakan semula jadi; sebahagiannya diisi

\section{INTRODUCTION}

Nanofluid as a working medium has been considered by many researchers for a simple reason, whereby due to the presence of nanoparticles, the thermal conductivity of the medium becomes enhanced. Thus, nanofluid seems to be a good candidate for its heat removal mechanisms in practical, thermal and fluid-based applications. Porous medium has been favorable in heat storage applications. Individually, in these two areas there has been a surge in research activity concerning natural convective heat transfer. A good number of excellent research papers and books present time testimony to this (Bejan et al. 2013; Kakac \& Pramuanjaroenkij 2009; Nield \& Bejan
2006; Pop \& Ingham 2001; Wang \& Mujumdar 2007). In lieu of the many different thermal problems possible to be investigated in the above two media. The very first comprehensive work on natural convection in partially filled nanofluids occupying enclosures was done by Khanafer et al. (2003). The study of Putra et al. (2003) investigated the natural convection inside a horizontal cylinder filled with nanofluids. The work of Jou and Tzeng (2006) considered natural convective heat transfer in nanofluids occupying a rectangular cavity.

Tiwari and Das (2007) considered the heat transfer in a lid-driven flow of nanofluid in a differentially heated square cavity. Santra et al. (2008) investigated enhanced 
heat transfer in Ostwald de Waele model based nanofluid, housed in a differentially heated cavity. Abouali and Falahatpisheh (2009) studied numerically the natural convection in vertical annuli filled with $\mathrm{Al}_{2} \mathrm{O}_{3}$ water nanofluid. Jahanshahi et al. (2010) made an experimental investigation of heat transfer in a cavity filled with a water-silicon dioxide nanofluid. Su et al. (2011) conducted experimentally the effect of nanoparticles on the physical properties of a binary nanofluid. Alloui et al. (2011) picked the water- $\mathrm{Al}_{2} \mathrm{O}_{3}$ nanofluid for the investigation of a shallow rectangular cavity using a finite volume method and a water-copper oxide nanofluid medium. Tham and Nazar (2012) studied numerically the laminar mixed convection boundary layer flow about a solid sphere embedded in a porous medium filled nanofluid. They considered three different types of nanoparticles $\left(\mathrm{Cu}, \mathrm{Al}_{2} \mathrm{O}_{3}\right.$ and $\left.\mathrm{TiO}_{2}\right)$ in water-based fluid. Heris et al. (2014) made a comparative experimental study on natural convective heat transfer in turbine oil-based nanofluid in an inclined cavity using different metal oxide nanoparticles. By using Tiwari and Das nanofluid model, Sheremet et al. (2015) investigated free convection in a squared porous cavity filled with nanofluid. Very recently, Jiang et al. (2015) considered the effect of thermal conductivity of carbon nanotube based nanofluid. Mohamed et al. (2016) used the Keller-box method to study the natural convection boundary layer flow in a horizontal circular cylinder embedded in a nanofluid with viscous dissipation effect.

Natural convection fluid flow and heat transfer in porous media domains has received considerable attention over the past few years and the prominence of this issue is due to the broad spectrum of industrial applications and environmental situations. It has exponentially been applied in geothermal systems, thermal insulation, filtration processes, ground water pollution, nuclear waste storage, drying processes, solidification of castings, storage of liquefied gases, biofilm growth and fuel cells. The phenomenon of fluid motions in clear region and porous medium has been explored extensively. The first attempts to study experimentally and analytically the natural convection flow and heat transfer between a porous media and a homogeneous fluid by focusing on the boundary condition at the fluid/porous interface were made by Beavers and Joseph (1967). Poulikakos et al. (1986) studied the high value of Rayleigh in natural convection in a fluid overlaying a porous bed, using Darcy model. Beckermann et al. (1987) observed natural convection flow and heat transfer between a fluid layer and a porous layer inside a rectangular enclosure. Natural convection heat and mass transfer in solidification were studied by Beckermann et al. (1988). Singh and Thorpe (1996) conducted a comparative study of different models for the investigation of natural convection in a confined fluid and overlying porous layer. Al-Nimr and Alkam (1998) considered the transient natural convection in parallel-plate channels partially filled with porous materials using non-Darcian model. Goyeau et al. (2003) discussed the problem of implementing one and twodomain formulations for the conservation equations. Chen et al. (2009) studied numerically the natural convection in a square cavity partially filled with porous layers on the top and bottom walls. Recently, Alsabery et al. (2015) investigated the natural convective flow and heat transfer in a cavity partially filled with porous media by using the finite element method. Using finite element method, Chamkha et al. (2016) studied the mixed convection in a square cavity partly filled with porous and partly with pure fluid and with inner rotating cylinder.

Most of the above mentioned studies focused on the natural convection heat transfer in square/rectangular cavities. In reality, natural convection in a differentially heated cavity is a prototype of several industrial applications and in specific, a trapezoidal cavity has received significant attention because of its applicability in various fields, a moderately concentrating solar energy collector is a significant model involving a trapezoidal geometry (Nasrin \& Parvin 2012). The problem of natural convection heat transfer in a trapezoidal cavity is difficult than that of square/rectangular cavities due to the presence of inclined walls. In general, the mesh nodes do not lie along the sloping walls and consequently, from a programming and computational point of view, the effort required for determining flow characteristic increases significantly. Lee (1984) firstly performed a numerical and experimental flow visualization study and heat transfer in a differently heated trapezoidal cavity filled with pure fluid. Karyakin (1989) has simulated the flow and temperature fields for various inclination angles of the sloping wall and showed that the heat transfer rate increases with the increasing angle of the sloping walls. However, no work has been reported in literature on natural convection fluid flow and heat transfer in trapezoidal cavity partly filled with a porous medium. Saleh et al. (2011) studied numerically the natural convection heat transfer in a trapezoidal cavity filled with water-Cu and water- $-\mathrm{Al}_{2} \mathrm{O}_{3}$ nanofluids. Chamkha and Ismael (2014) conducted for the first time a numerical study to solve the problem of differentially heated and vertically partially layered porous cavity filled with nanofluid on natural convection by using the Darcy-Brinkman model.

Nevertheless, the study of Darcian natural convection fluid flow and heat transfer in a trapezoidal cavity partially filled with porous medium has not been undertaken yet. The aim of this study was to investigate the Darcian natural convection in an inclined trapezoidal cavity partly filled with porous and partly with nanofluid. The results have possible applications in heat-removal and heat-storage fluid-saturated porous systems like solar energy systems and nuclear energy systems. The study of the effect of uniform temperatures variation on the trapezoidal domain has many important engineering applications, for example, when we consider the effect of uniform temperatures variation of a solar energy collector, a periodic array of heater and cooler are placed on the inclined walls of the trapezoidal domain. 


\section{MATHEMATICAL FORMULATION}

Consider a two-dimensional natural convection of a trapezoidal cavity with length $L$; the left cavity part is filled with porous $W$, while the remainder of the cavity $(L-W)$ is filled with nanofluid, as illustrated in Figure 1. The left sloping wall of the cavity is heated to a constant temperature $T_{h}$ and the right sloping wall is maintained at a constant cold temperature $T$, while the horizontal walls are adiabatic. The outer boundaries are assumed to be impermeable, while the interface boundary (between the two layers) is assumed to be permeable. The pores filled with fluid composed from water-base nanofluids containing $\mathrm{Ag}, \mathrm{Cu}$ or $\mathrm{TiO}_{2}$ nanoparticles. According to the Boussinesq approximation, the fluid physical properties are constant except for the density. By considering these assumptions, the conservation equations for mass, Darcy and energy equations for steady natural convection of the fluid and the porous layer will be considered separately. For the homogenous porous layer we have:

$$
\begin{aligned}
& \frac{\partial u_{p}}{\partial x}+\frac{\partial v_{p}}{\partial y}=0 \\
& u_{p}=-\frac{K_{p}}{\mu} \frac{\partial p_{p}}{\partial x}+\frac{K_{p} \beta_{p} g}{v}\left(T_{p}-T_{c}\right) \cos \varpi, \\
& v_{p}=-\frac{K_{p}}{\mu} \frac{\partial p_{p}}{\partial y}+\frac{K_{p} \beta_{p} g}{v}\left(T_{p}-T_{c}\right) \sin \varpi, \\
& u_{p} \frac{\partial T_{p}}{\partial x}+v_{p} \frac{\partial T_{p}}{\partial y}=\frac{\partial^{2} T_{p}}{\partial x^{2}}+\frac{\partial^{2} T_{p}}{\partial y^{2}},
\end{aligned}
$$

The conservation equations for mass, momentum and energy equations for nanofluid layer are:

$$
\begin{aligned}
& \frac{\partial u_{n f}}{\partial x}+\frac{\partial v_{n f}}{\partial y}=0 \\
& u_{n f} \frac{\partial u_{n f}}{\partial x}+v_{n f} \frac{\partial u_{n f}}{\partial y}=-\frac{1}{\rho_{n f}} \frac{\partial p_{n f}}{\partial x} \\
& +v_{n f}\left(\frac{\partial^{2} u_{n f}}{\partial x^{2}}+\frac{\partial^{2} u_{n f}}{\partial y^{2}}\right)+\beta_{n f} g \sin \varpi\left(T_{n f}-T_{c}\right), \\
& u_{n f} \frac{\partial v_{n f}}{\partial x}+v_{f} \frac{\partial v_{n f}}{\partial y}=-\frac{1}{\rho_{n f}} \frac{\partial p_{n f}}{\partial y} \\
& +v_{n f}\left(\frac{\partial^{2} v_{n f}}{\partial x^{2}}+\frac{\partial^{2} v_{n f}}{\partial y^{2}}\right)+\beta_{n f} g \cos \varpi\left(T_{n f}-T_{c}\right), \\
& u_{n f} \frac{\partial T_{n f}}{\partial x}+v_{n f} \frac{\partial T_{n f}}{\partial y}=\alpha_{n f}\left(\frac{\partial^{2} T_{n f}}{\partial x^{2}}+\frac{\partial^{2} T_{n f}}{\partial y^{2}}\right) .
\end{aligned}
$$

where $x$ and $y$ are the Cartesian coordinates measured in the horizontal and vertical directions, respectively, $K$ is the permeability of the porous medium and $g$ is the acceleration due to gravity, $\phi$ is the solid volume fraction of nanoparticles. $\alpha_{n f}$ is the effective thermal diffusivity of the nanofluids, $\rho_{n f}$ is the effective density of the nanofluids and $\mu_{n f}$ is the effective dynamic viscosity of the nanofluids and which are defined as

$$
\alpha_{n f}=\frac{k_{n f}}{(\rho C p)_{n f}}, \rho_{n f}=(1-\phi) \rho_{b f}+\phi \rho_{s p}, \frac{\mu_{n f}}{\mu_{b f}}=\frac{1}{(1-\phi)^{2.5}} .
$$

where, the heat capacitance of the nanofluids given is:

$$
(\rho C p)_{n f}=(1-\phi)(\rho C p)_{b f}+\phi(\rho C p)_{s p} .
$$

The thermal expansion coefficient of the nanofluids can be determined by:

$$
\begin{aligned}
& \beta_{n f}=(1-\phi)(\beta)_{b f}+\phi \beta_{s p}, \\
& (\rho \beta)_{n f}=(1-\phi)(\rho \beta)_{b f}+\phi(\rho \beta)_{s p} .
\end{aligned}
$$

The thermal conductivity based on Maxwell-Garnett's (MG) model is given:

$$
\frac{k_{n f}}{k_{b f}}=\frac{k_{s p}+2 k_{b f}-2 \phi\left(k_{b f}-k_{s p}\right)}{k_{s p}+2 k_{b f}+\phi\left(k_{b f}-k_{s p}\right)} .
$$

In terms of the stream function $\psi$ and the vorticity $\omega$, which are defined in the usual way as:

$$
\begin{aligned}
& u=\frac{\partial \psi}{\partial y}, v=-\frac{\partial \psi}{\partial x} \\
& \omega=\frac{\partial \psi}{\partial x}-\frac{\partial \psi}{\partial y} .
\end{aligned}
$$

Now we introduce the following non-dimensional variables:

$$
\begin{aligned}
& X=\frac{x}{L}, Y=\frac{y}{L}, \Omega=\frac{\omega L^{2}}{\alpha_{b f}}, \Psi=\frac{\psi}{\alpha_{b f}}, \\
& \theta_{n f}=\frac{T_{n f}-T_{c}}{T_{h}-T_{c}}, \theta_{p}=\frac{T_{p}-T_{c}}{T_{h}-T_{c}} .
\end{aligned}
$$

This then yields the dimensionless governing equations forms for porous layer,

$$
\begin{aligned}
& \frac{\partial^{2} \Psi_{p}}{\partial X^{2}}+\frac{\partial^{2} \Psi_{p}}{\partial Y^{2}}=\text { DaRa }\left(\cos \varpi \frac{\partial \theta_{p}}{\partial X}-\sin \varpi \frac{\partial \theta_{p}}{\partial Y}\right), \\
& \frac{\partial \Psi_{p}}{\partial X} \frac{\partial \theta_{p}}{\partial Y}-\frac{\partial \Psi_{p}}{\partial Y} \frac{\partial \theta_{p}}{\partial X}=\frac{k_{p}}{k_{n f}}\left(\frac{\partial^{2} \theta_{p}}{\partial X^{2}}+\frac{\partial^{2} \theta_{p}}{\partial Y^{2}}\right) .
\end{aligned}
$$

This then yields the dimensionless governing equations forms for nanofluid layer, 


$$
\begin{aligned}
& \frac{\partial^{2} \Psi_{n f}}{\partial X^{2}}+\frac{\partial^{2} \Psi_{n f}}{\partial Y^{2}}=-\Omega_{n f}, \\
& \frac{\partial \Psi_{n f}}{\partial Y} \frac{\partial \Omega_{n f}}{\partial X}-\frac{\partial \Psi_{n f}}{\partial X} \frac{\partial \Omega_{n f}}{\partial Y}=\frac{\mu_{n f}}{\mu_{b f}}\left[\frac{P r}{(1-\phi)+\phi \frac{\rho_{s p}}{\rho_{b f}}}\right]\left(\frac{\partial^{2} \Omega_{n f}}{\partial X^{2}}+\frac{\partial^{2} \Omega_{n f}}{\partial Y^{2}}\right) \\
& \quad+\frac{\beta_{n f}}{\beta_{b f}} \operatorname{RaPr}\left(\cos \varpi \frac{\partial \theta_{n f}}{\partial X}-\sin \varpi \frac{\partial \theta_{n f}}{\partial Y}\right), \\
& \frac{\partial \Psi_{n f}}{\partial Y} \frac{\partial \theta_{n f}}{\partial X}-\frac{\partial \Psi_{n f}}{\partial X} \frac{\partial \theta_{n f}}{\partial Y}=\frac{\left(\rho C_{p}\right)_{b f}}{\left(\rho C_{p}\right)_{n f}} \frac{k_{n f}}{k_{b f}}\left(\frac{\partial^{2} \theta_{n f}}{\partial X^{2}}+\frac{\partial^{2} \theta_{n f}}{\partial Y^{2}}\right),
\end{aligned}
$$

where $R a=g K \rho_{f b} \beta_{b f}\left(T_{h}-T_{c}\right) L^{3} /\left(\mu_{b f} \alpha_{b f}\right)$ is the Rayleigh number for both the fluid and the porous layer, $D a=K /$ $L^{2}$ is the Darcy number for the porous layer and nanofluid layer and $\operatorname{Pr}=v_{b f} / \alpha_{b f}$ is the Prandtl number for both porous layer and nanofluid layer. The dimensionless boundary conditions of (17)-(21) are:

$$
\begin{aligned}
& \Omega=-\frac{\partial^{2} \Psi}{\partial X^{2}}, \quad \theta=\theta_{p}=1 \text { on } \mathrm{AD}, \\
& \Omega=-\frac{\partial^{2} \Psi}{\partial X^{2}}, \theta=\theta_{n f}=0 \text { on } \mathrm{BC}, \\
& \Omega=-\frac{\partial^{2} \Psi}{\partial Y^{2}}, \frac{\partial \theta_{p}}{\partial Y}=\frac{\partial \theta_{n f}}{\partial Y}=0 \text { on } \mathrm{AB} \text { and } \mathrm{DC},
\end{aligned}
$$

and at the interface by using the matching conditions proposed by Beavers and Joseph (1967),

$$
\begin{gathered}
\Psi^{+}=\Psi^{-}, \frac{\partial \Psi^{+}}{\partial X}=\frac{\partial \Psi^{-}}{\partial X}, \\
\frac{\partial^{2} \Psi^{+}}{\partial X^{2}}=\bar{\alpha}\left(\frac{\partial \Psi^{+}}{\partial X}-\frac{\partial \Psi^{-}}{\partial X}\right) / \sqrt{D a}, \\
\left.\theta\right|_{X=s^{+}}=\left.\theta\right|_{X=s^{-}}, \\
k_{n f} \frac{\partial \theta}{\partial X} s^{+}=k_{p} \frac{\partial \theta}{\partial X} s^{-}, \\
\Omega^{+}=\frac{\partial^{2} \Psi^{+}}{\partial X^{2}}+\frac{\partial^{2} \Psi^{+}}{\partial Y^{2}},
\end{gathered}
$$

where in our study the value of $\bar{\alpha}$ fix at and the subscripts + and-indicate that the respective quantities are evaluated while approaching the interface from the nanofluid and porous layers, respectively.

The average Nusselt number evaluated at the hot sloping left wall is:

$$
\overline{N u}=\int_{A}^{D}\left[-\left(\frac{k_{n f}}{k_{b f}}\right) \frac{\partial \theta_{p}}{\partial X}\right] \mathrm{d} Y .
$$

\section{NUMERICAL METHOD AND VALIDATION}

We employ finite difference method to solve the governing equation. The central difference method is applied for discretizing the equations. A correct illustration of vorticity on the surface is essentially the most critical step in the stream perform vorticity formulation. A second-order exact components is applied for the vorticity boundary condition. For instance, the vorticity on the right wall is stated as:

$$
\Omega=-\frac{\left(8 \Psi_{N x+1, j}-\Psi_{N x, j}\right)}{2(\Delta X)^{2}},
$$

where $N x+1$ is the number of nodal points in the $X$-axis. Similar expressions are written for top and bottom walls. The vorticity at the interface is expressed as:

$$
\begin{aligned}
\left(\Omega_{n f}\right)_{N s+1, j}= & -\frac{\left(\Psi_{n f}\right)_{N s+3, j}-2\left(\Psi_{n f}\right)_{N s+2, j}+\left(\Psi_{n f}\right)_{N s+1, j}}{\Delta X^{2}} \\
& -\frac{\left(\Psi_{n f}\right)_{N s+1, j+1}-2\left(\Psi_{n f}\right)_{N s+1, j}+\left(\Psi_{n f}\right)_{N s+1, j-1}}{\Delta Y^{2}},
\end{aligned}
$$

where $N s+1$ is the number of nodal points in the porous region in the horizontal direction. The conditions of temperature at the interface boundary are:

$$
\begin{aligned}
\left(\theta_{n f}\right)_{N s+1, j}^{k+1}= & \left(\theta_{p}\right)_{N s+1, j}^{k} \\
\left(\theta_{p}\right)_{N s+1, j}^{k+1}= & \frac{1}{3}\left[\frac{k_{n f}}{k_{p}}\left(-\left(\theta_{n f}\right)_{N s+3, j}^{k}+4\left(\theta_{n f}\right)_{N s+2, j}^{k}-3\left(\theta_{n f}\right)_{N s+1, j}^{k}\right)\right. \\
& \left.+4\left(\theta_{p}\right)_{N s+1, j}^{k}-\left(\theta_{p}\right)_{N s, j}^{k}\right] .
\end{aligned}
$$

Regular and uniform grid distribution is used for the whole enclosure. The effect of grid resolution was examined in order to select the appropriate grid density. We use a $160 \times 160$ grid in the final computations. In order to validate the computation code, comparison of present $\overline{\mathrm{Nu}}$ for different values of $S$ when $R a=10^{5}$ and $\operatorname{Pr}=0.71$ with some previous published results were made in Table 1 . These results provide confidence to the accuracy of the present numerical method.

TABLE 1. Comparison of $\overline{\mathrm{Nu}}$ for different values of $S$ when $R a=10^{5}$ and $\operatorname{Pr}=0.71$ with some previous numerical results

\begin{tabular}{cccc}
\hline$S$ & $\begin{array}{c}\text { Present } \\
\text { study }\end{array}$ & $\begin{array}{c}\text { Sathe et al. } \\
(1988)\end{array}$ & $\begin{array}{c}\text { Mharzi et al. } \\
(2000)\end{array}$ \\
\hline 0.25 & 3.103 & 3.083 & 3.101 \\
0.50 & 3.350 & 3.321 & 3.348 \\
0.75 & 3.605 & 3.600 & 3.604 \\
\hline
\end{tabular}

\section{RESULTS AND DISCUSSION}

In this section, we present numerical results for the streamlines of porous/nanofluid layer and isotherms of porous/nanofluid-layer with various values of Rayleigh number $\left(10^{4} \leq R a \leq 10^{7}\right)$, Darcy number $\left(10^{-5} \leq D a \leq\right.$ 
$\left.10^{-3}\right)$, nanoparticle volume fraction $(0 \leq \phi \leq 0.2)$, porous layer thickness $(0.3 \leq S \leq 0.7)$, the side wall inclination angle $\left(0^{\circ} \leq \varphi \leq 21.8^{\circ}\right)$, the inclination angle of the cavity $\left(0^{\circ} \leq \varpi \leq 90^{\circ}\right)$ and Prandtl number $(P r=6.2)$. The values of the average Nusselt number were calculated for various values of $R a, \phi$ and $\varpi$. Before we move on to the discussion of the results, it is worthwhile to know the values for quantities of base fluid, nanoparticles and effective thermal conductivity concerning the nanofluid. These are presented in Tables 2 and 3. From Table 3, it is apparent that the thermal conductivity, $k_{n f}$, increases with the increase of $\phi$ but the rates at which they increase determines their role, either enhancing or diminishing heat transfers. It should also be mentioned that the parametric values used in conducting the parametric study are taken from previously published work and in the absence of a specific application, the parametric study would serve as a vehicle for qualitative understanding of the effects of the various parameters on the physics of the problem.

TABLE 2. Thermo-physical properties of water with $\mathrm{Ag}, \mathrm{Cu}$ and $\mathrm{TiO}_{2}$

\begin{tabular}{ccccc}
\hline $\begin{array}{c}\text { Properties } \\
\text { Physical }\end{array}$ & Water & $\mathrm{Ag}$ & $\mathrm{Cu}$ & $\mathrm{TiO}_{2}$ \\
\hline$C p(J / k g K)$ & 4179 & 235 & 383 & 686.2 \\
$\rho\left(k g / m^{3}\right)$ & 997.1 & 10500 & 8954 & 4250 \\
$k\left(W m^{-1} K^{-1}\right)$ & 0.6 & 429 & 400 & 8.954 \\
$\beta \times 10^{-5}(1 / K)$ & 21 & 5.4 & 1.67 & 2.4 \\
\hline
\end{tabular}

TABLE 3. Effective thermal conductivity values of nanofluids at $300^{\circ} \mathrm{K}$

\begin{tabular}{ccc}
\hline Nanofluid & $\phi$ & $k_{n f}$ \\
\hline Water-Ag & 0.05 & 0.694 \\
& 0.10 & 0.799 \\
& 0.15 & 0.916 \\
& 0.20 & 1.048 \\
Water-Cu & & \\
& 0.05 & 0.694 \\
& 0.10 & 0.799 \\
& 0.15 & 0.916 \\
Water-TiO & 0.20 & 1.047 \\
& & \\
& 0.05 & 0.677 \\
& 0.10 & 0.761 \\
& 0.15 & 0.853 \\
& 0.20 & 0.954 \\
\hline
\end{tabular}

Figure 2 shows the effects of various Rayleigh numbers on the streamlines (left) and isotherms (right) for water- $\mathrm{Cu}$ nanoparticles with Darcy number $\left(\mathrm{Da}=10^{-4}\right)$, porous layer thickness $(S=0.5)$, side wall inclination angle $\left(\varphi=16.7^{\circ}\right)$ and inclination angle of the cavity $\left(\varpi=0^{\circ}\right)$.
In the scope of the present study, Figure 2(a) demonstrates the streamlines and isotherm patterns at lower values of the Rayleigh number $\left(10^{5}\right)$. Heating the left wall of the cavity leads to the rise of the flow inside the cavity, as such the flow begins to move from the left wall (hot) (porous partition) to the right wall (cold) by infiltrating into the nanofluid layer, descending along the right wall and then ascending again at the hot wall, creating a clockwise rotating cell inside the cavity (nanofluid partition). The flow circulation of the streamline cells for nanofluids is bigger than that for pure fluids into the nanofluid layer, while being similar in size within the porous layer, due to higher thermal conductivity of the nanofluid. When the streamlines circulate as vortices in the clockwise direction (negative signs of $\Psi$ ), the strength of the flow circulation is presented by $\Psi_{\min }$. The conduction heat transfer forces the isotherm patterns within the porous layer to take almost a vertical shape; meanwhile, the convection mode heat transfer affects the isotherm patterns within the nanofluid layer to appear in horizontal lines to the slopping walls. As the nanoparticle volume fraction is applied $(\phi=0.05)$, the circulation intensity increases (see $\Psi_{\min }$ values) due to the increase in thermal conductivity. The streamline intensity near to the slopping walls increases as increases. The increase in the strength of the flow circulation can be observed with increasing values of (see $\Psi_{\min }$ values). As the nanoparticle volume fraction is applied $(\phi=0.05)$, the circulation intensity increases (see $\Psi_{\min }$ values) due to the increase in the thermal conductivity of the nanofluid, as shown in Figure 2(b). The streamline circulation cell into the nanofluid layer extends towards the bottom wall. The distortion of the isotherm patterns is enhanced as $R a$ is increased $\left(R a=10^{6}\right)$; the vertical isotherm patterns into the porous layer tend to become diagonal lines, while into the nanofluid layer the diagonal lines tend to take the shape of a horizontal line. A significant modification in the streamlines and isotherm patterns is presented in Figure 2(c); at higher $R a$, the streamline circulation cell into the nanofluid layer extends horizontally along the cavity, the streamline intensity increases noticeably near to the slopping walls (left and right). The flow circulation of the streamline cells for nanofluid becomes almost similar to that of pure fluid, due to the higher Rayleigh number.

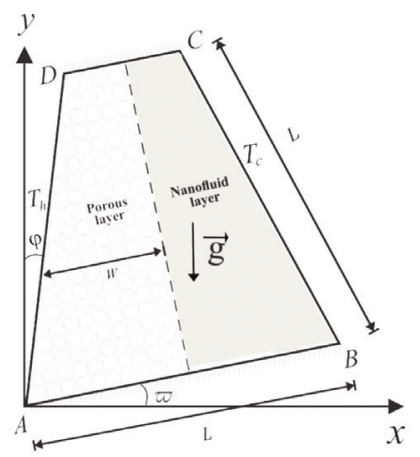

FIGURE 1. Physical model of convection in a trapezoidal porous cavity together with the coordinate system 
Figure 3 depicts the effect of porous layer thickness on the streamlines (left) and isotherms (right) for water$\mathrm{Cu}$ nanoparticles, $R a=10^{6}, D a=10^{-4}, \varphi=16.7^{\circ}$ and $\varpi$ $=0^{\circ}$. The effect of lower value of $S(0.3)$ on the flow motion with the boundary condition sets is demonstrated in Figure 3(a), in which the streamlines tend to appear with high intensity close to the slopping walls and with a non-uniform semi-rectangular cell within the nanofluid layer. The strength of the flow circulation increases $\left(\Psi_{\min }\right.$ values) by the nanofluid addition and is due to the increase in thermal conductivity. The conduction heat transfer forces the isotherm patterns within the porous layer to take almost a diagonal shape, while the convection mode heat transfer affects the isotherm patterns within the nanofluid layer to appear with horizontal lines to the slopping walls. By increasing the porous layer thickness $(S=0.5)$, the streamline circulation cell within the nanofluid layer shrinks, thus transforming into a semi-oval shape. The strength of the flow circulation decreases for both pure fluid and nanofluid with increasing values of $S$ ( $\Psi_{\min }$ values), due to the hydrodynamic resistance of the nanofluid layer. The isotherm patterns near the interface tend to take almost a horizontal shape, enhanced by the convection heat transfer, while the isotherm patterns close to the slopping walls remain within vertical lines, as illustrated in Figure 3(b). At the higher $S$ value $(S=0.7)$, the streamlines are significantly affected; the streamline circulation cell takes place between the porous layer and nanofluid layer. The strength of the flow circulation decreases by the addition of of $\mathrm{Cu}$ nanoparticles which lowers the thermal conductivity of pure fluid, as shown in Figure 3(c).

The effects of the side wall inclination angle on the streamlines (left) and isotherms (right) are illustrated in Figure 4 for water-Cu nanoparticles, $R a=10^{6}, D a=$ $10^{-4}, S=0.5$ and $\varpi=0^{\circ}$. Figure 4(a) depicts the effect of changing the flow motion with the boundary conditions set without the side wall inclination angle $\left(\varphi=0^{\circ}\right)$, i.e. square cavity. Due to higher amount of the flow velocity, the maximum strength of the flow circulation is achieved for the streamlines of the pure fluid and nanofluid for the square cavity. The flow circulation cell of the streamlines for pure fluid is much bigger than that for nanofluid. As

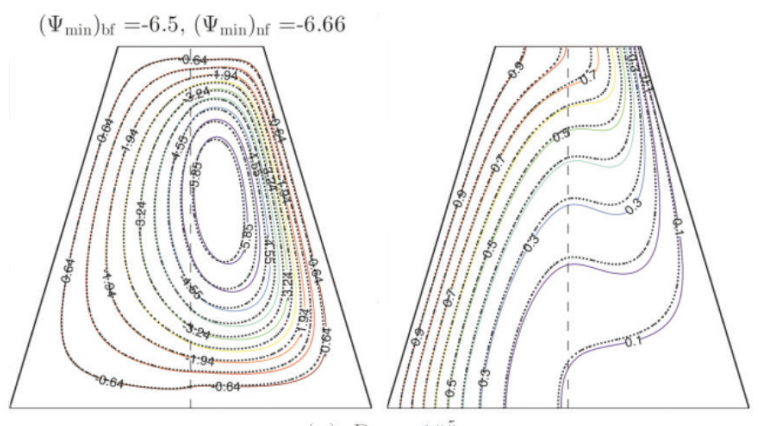

(a) $R a=10^{5}$
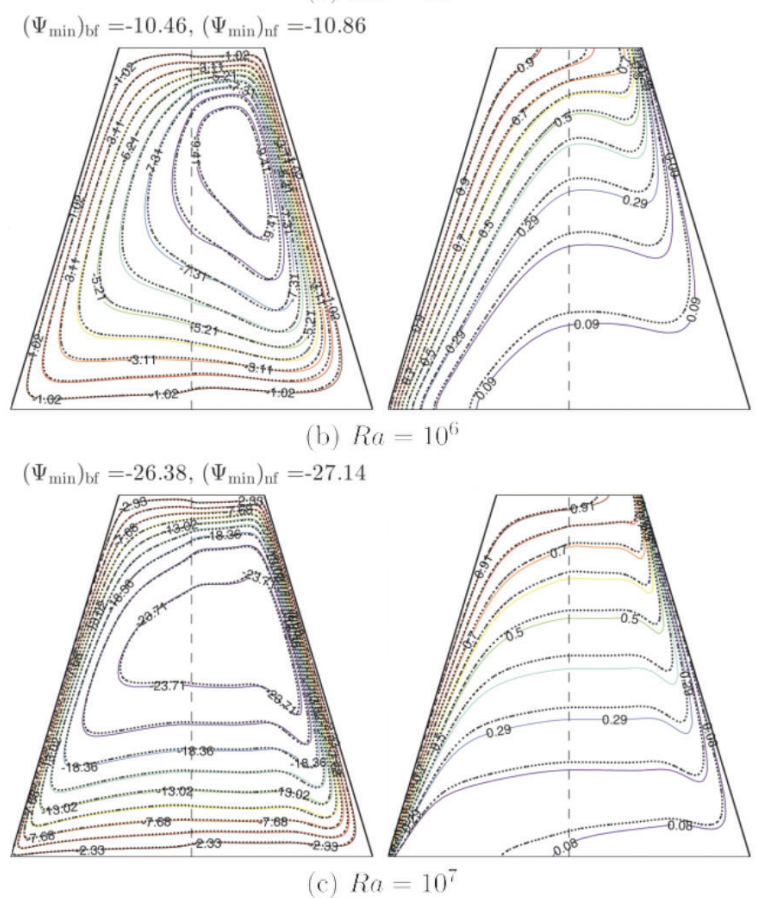

FIGURE 2. Streamlines (left) and isotherms (right) evolution by Rayleigh number for $D a=10^{-4}$, $S=0.5, \varphi=16.7^{\circ}, \varpi=0^{\circ}, \phi=0$ (solid lines) and $\phi=0.05$ (dashed lines) 


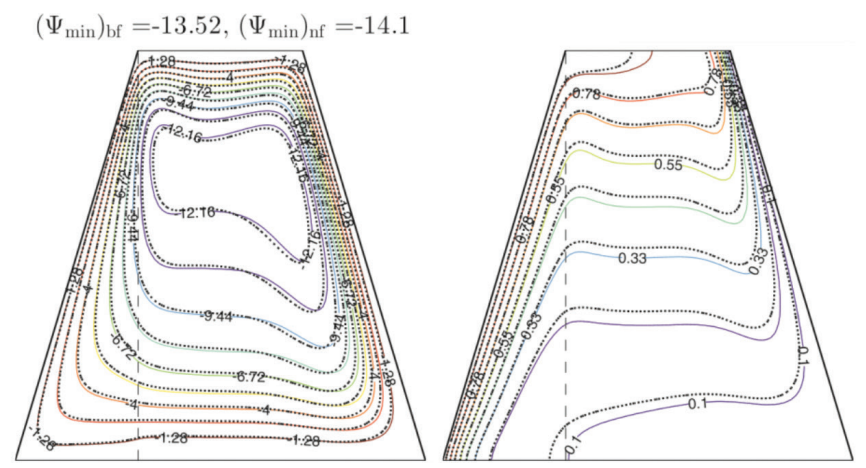

(a) $S=0.3$
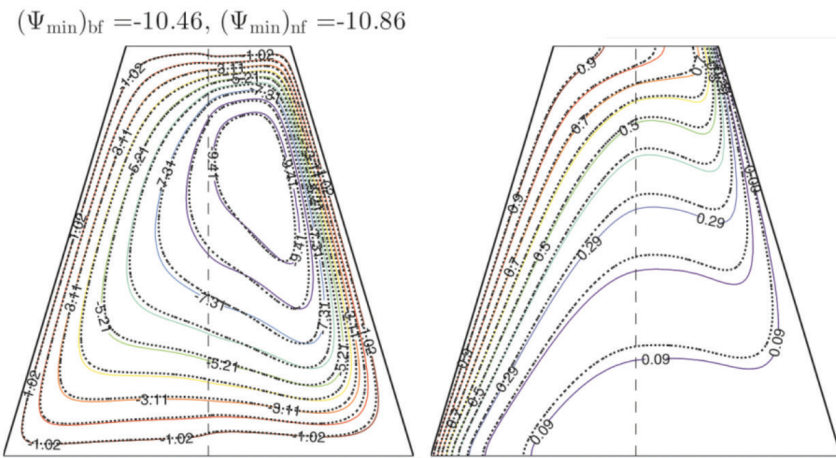

(b) $S=0.5$

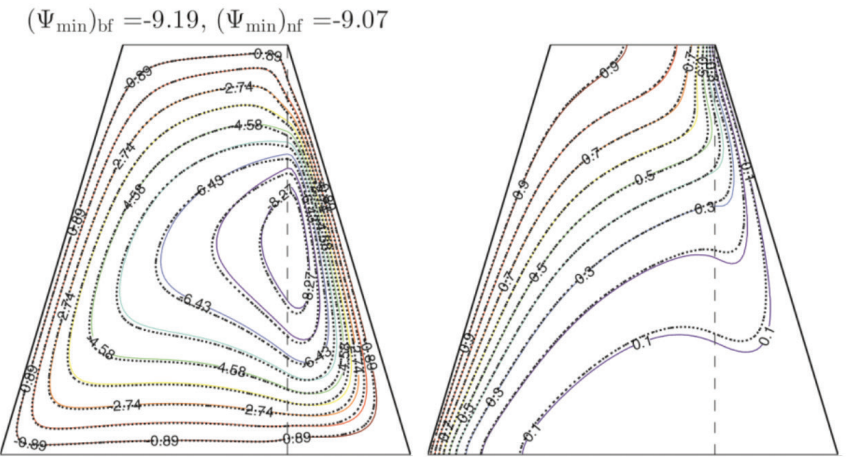

(c) $S=0.7$

FIGURE 3. Streamlines (left) and isotherms (right) evolution by porous layer thickness for $R a=10^{6}, D a=10^{-4}, \varphi=16.7^{\circ}, \varpi=0^{\circ}, \phi=0$ (solid lines) and $\phi=0.05$ (dashed lines)

the nanoparticle volume fraction is applied $(\phi=0.05)$, the circulation intensity increases ( $\Psi_{\min }$ values). Enforcing a lower $\varphi\left(\varphi=1.3^{\circ}\right)$ leads to a decrease of the intensity of streamlines for pure fluid and nanofluid; as a result, the strength of the flow circulation for the streamlines decreases ( $\Psi_{\min }$ values). Increasing $\phi$ value tends to increase the isotherm pattern intensity, which is affected by the cavity types as presented in Figure 4(b). The flow circulation cell of the streamlines for pure fluid becomes almost similar to that for nanofluid as $\varphi$ increases. The distortion of the isotherms is enhanced, a result of higher $\varphi$ value, as shown in Figure 4(c).

Figure 5 demonstrates the effect of inclination angle of the cavity on the streamlines (left) and isotherms (right) for water-Cu nanoparticles, $R a=10^{6}, D a=10^{-4}, S=0.5$ and $\varphi=18.7^{\circ}$. Applying lower inclination angle $\left(\varpi=30^{\circ}\right)$ is clearly affected the flow motion and the temperature profile as shown in Figure 5(a). The streamlines appear with high intensity within the nanofluid layer and with singular cell in clockwise direction. The strength of the flow circulation in the clockwise direction decreases with the addition of of $\mathrm{Cu}$ nanoparticles ( $\Psi_{\min }$ values). The isotherm patterns within the cavity tend to take a vertical shape due to the effect of lower inclination angle. Increasing the inclination angle up to is clearly enhanced the flow movement and the temperature distribution. The streamlines circulation cell increases and move toward the interface. The strength of the flow circulation is switched into the anti-clockwise direction (positive signs of $\Psi$ ) with the increment of the inclination angle of the cavity. The flow circulation of the streamline cells into the porous layer appear higher than that within the nanofluid layer due to the effect of the inclination angle of the cavity. The reason for this behavior is that the movement of the flow become more like applying 


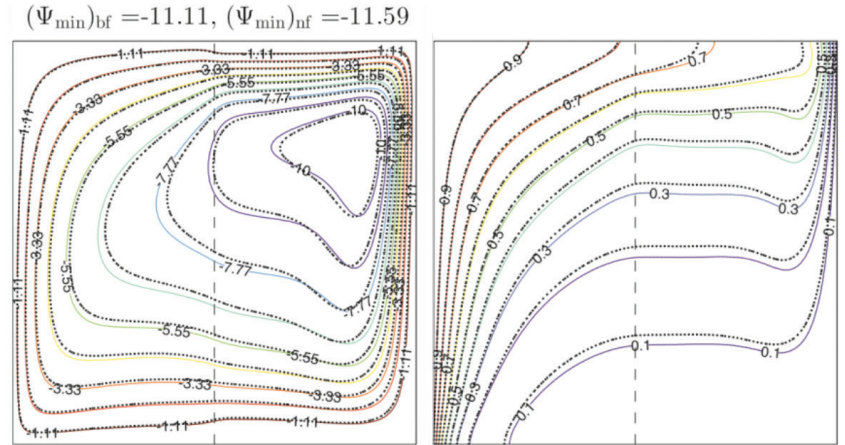

(a) $\varphi=0^{\circ}$

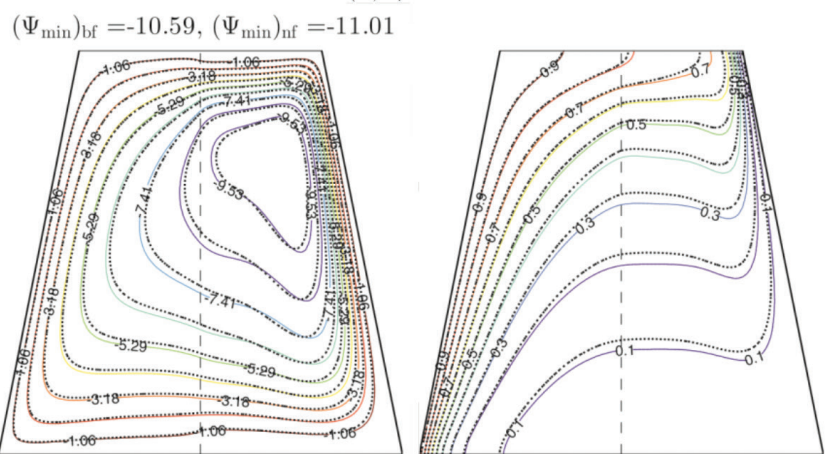

(b) $\varphi=11.3^{\circ}$

$\left(\Psi_{\min }\right)_{\mathrm{bf}}=-10.75,\left(\Psi_{\min }\right)_{\mathrm{nf}}=-11.17$

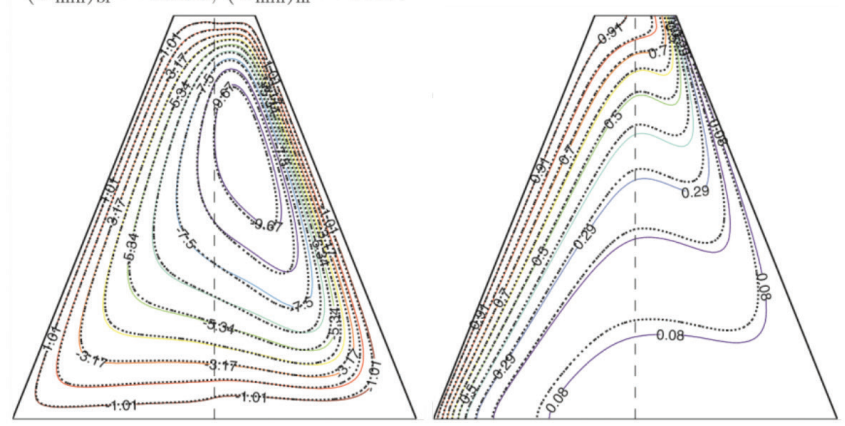

(c) $\varphi=21.8^{\circ}$

FIGURE 4. Streamlines (left) and isotherms (right) evolution by the side wall inclination angle for $R a=10^{5}, D a=10^{-3}, S=0.5, \varpi=0^{\circ}, \phi=0$ (solid lines) and $\phi=0.05$ (dashed lines)

heating from below or Bnard convection problem. The gravitational force pushes the fluid flow circulation and tends to change the flow direction, as illustrated in Figure 5(b) and 5(c).

Figure 6(a) shows the effect of Darcy number on the average Nusselt number with Rayleigh number for water- $\mathrm{Cu}$ at $\phi=0.05, S=0.5, \varphi=16.7^{\circ}$ and $\varpi=0^{\circ}$. Naturally, the convection heat transfer is increased by increasing the Rayleigh number, by which significant enhancement occurs at high Rayleigh number $\left(R a>10^{5}\right)$, whereas lower Rayleigh number values have less effect on the convection. The maximum Darcy number $(D a=$ $10^{-3}$ ) leads to a stronger convection, but this value also drops at higher Rayleigh number $\left(R a>10^{6}\right)$. Figure 6(b) summarizes the variations in the average Nusselt numbers with Rayleigh number for different nanoparticle volume fractions of water-Cu at $D a=10^{-4}, S=0.5, \varphi=16.7^{\circ}$ and $\varpi=0^{\circ}$. The heat transfer rate is increased by the increase of Rayleigh number; a higher concentration of nanoparticle volume fractions $(\phi=0.2)$ leads to a higher average Nusselt number. Significant enhancement in the convection heat transfer appears with higher values of Rayleigh number $\left(R a \geq 10^{6}\right)$.

Figure 7(a) depicts the effect of various porous layer thickness on the average Nusselt number with Rayleigh number for water-Cu at $\mathrm{Da}=10^{-4}, \phi=0.05, \varphi=16.7^{\circ}$ and $\varpi=0^{\circ}$. As a result, the convection heat transfer enhancement occurs significantly at higher Rayleigh number $\left(R a \geq 10^{6}\right)$, while low Rayleigh number values have less effect on the heat transfer rate. Increasing Rayleigh number leads to the increase in the average Nusselt number; smaller porous layer thickness has a stronger effect on the heat transfer rate, which has higher average Nusselt number. Figure 7(b) demonstrates the effect of 


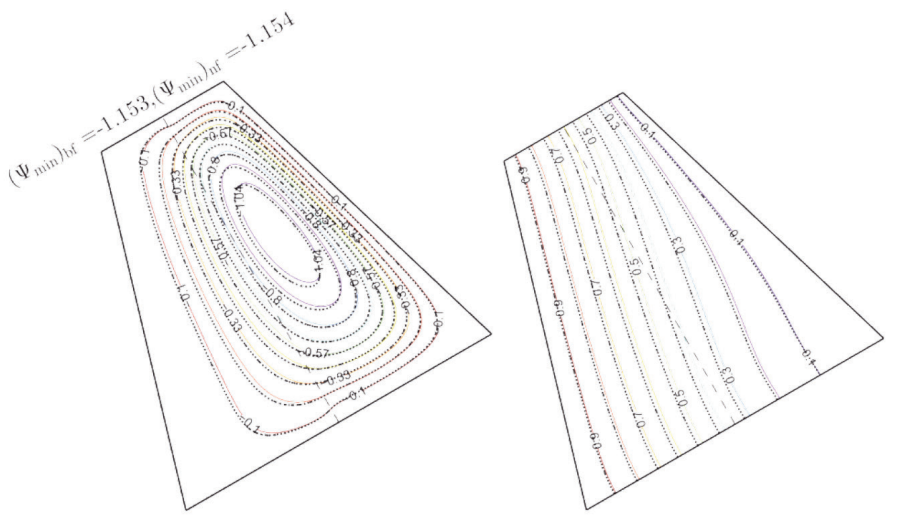

(a) $\varpi=30^{\circ}$

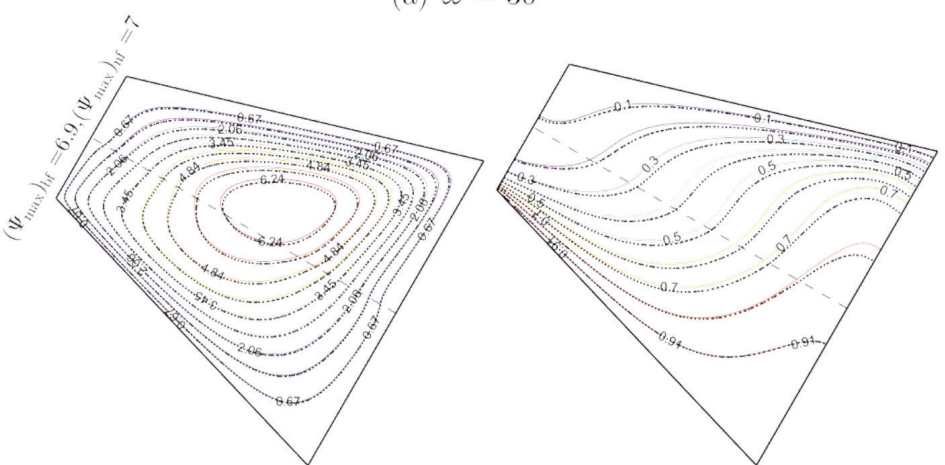

(b) $\varpi=60^{\circ}$

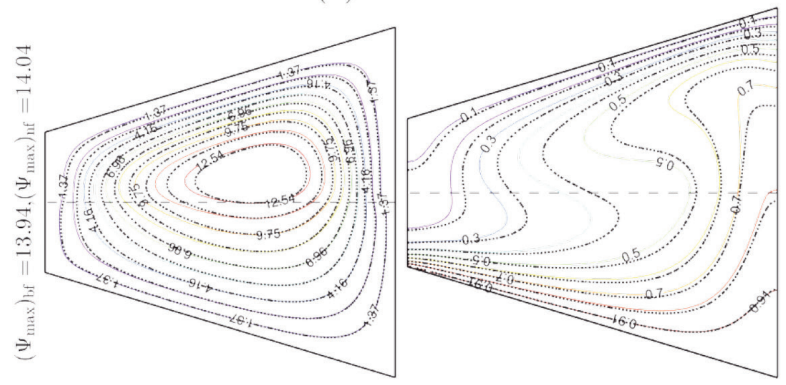

(c) $\varpi=90^{\circ}$

FIGURE 5. Streamlines (left) and isotherms (right) evolution by the inclination angle of the cavity for $R a=10^{5}, D a=10^{-3}, S=0.5, \varphi=16.7^{\circ}, \phi=0$ (solid lines) and $\phi=0.05$ (dashed lines)

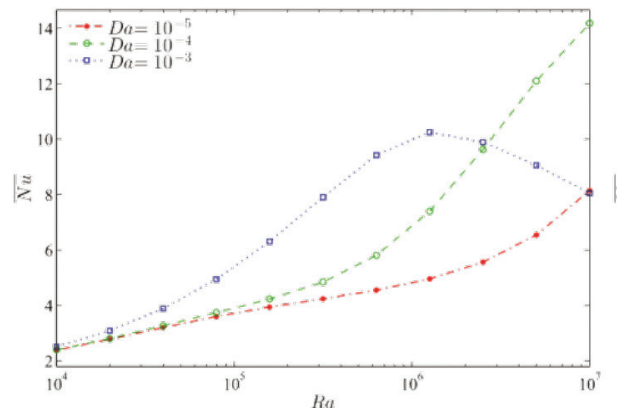

(a)

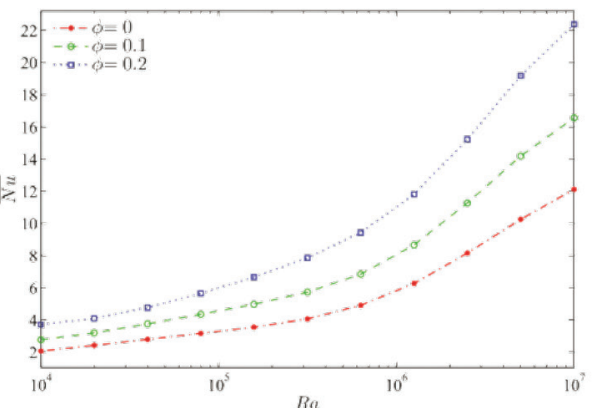

(b)

FIGURE 6. Variation of the average Nusselt number interfaces with $R a$ for different (a) $D a$, (b) $\phi$ at $S=0.5, \varphi=16.7^{\circ}$ and $\varpi=0^{\circ}$ 


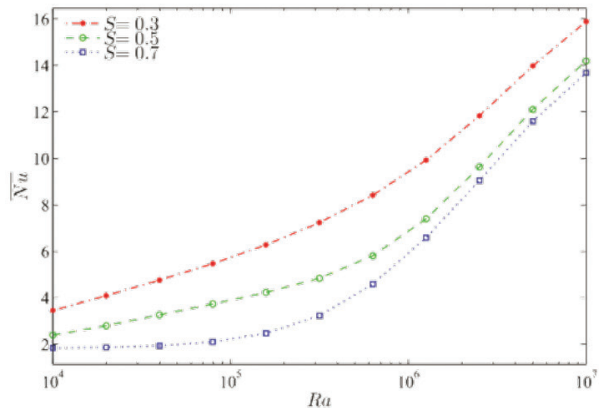

(a)

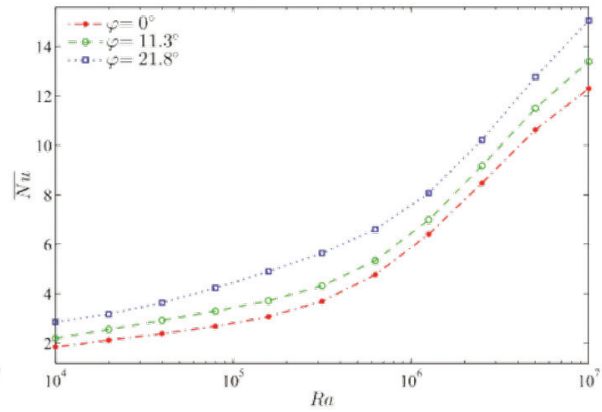

(b)

FIGURE 7. Variation of the average Nusselt number interfaces with for $R a$ different

(a) $S$, (b) $\varphi$ at $D a=10^{-4}, \phi=0.05$ and $\varpi=0^{\circ}$

various side wall inclination angles on the average Nusselt number with Rayleigh number for water-Cu at $D a=10^{-4}$, $\phi=0.05, S=0.5$ and $\varpi=0^{\circ}$. Clearly, heat transfer rate is enhanced by increasing Rayleigh number; consequently, the average Nusselt number increases. Significant increase in average Nusselt number occurs for high Rayleigh number $\left(R a=10^{5}\right)$; higher $\varphi$ value $\left(\varphi=21.8^{\circ}\right)$ leads to strong enhancements in the heat transfer rate with the maximum value for the average Nusselt number.

Figure 8(a) presents the effect of various nanoparticles on the average Nusselt number with nanoparticle volume fractions at $R a=10^{6}, D a=10^{-4}, S=0.5, \varphi=16.7^{\circ}$ and $\varpi=0^{\circ}$. Due to its higher thermal conductivity, Ag helps water in transporting more heat compared to that with $\mathrm{Cu}$ and $\mathrm{TiO}_{2}$ nanoparticles, which is also shown in Table 3 . Weak enhancement appears in the convection by applying $\mathrm{TiO}_{2}$ nanoparticles as the nanoparticle volume fraction increases. However, it is $\mathrm{Cu}$ that transports marginally more heat than $\mathrm{TiO}_{2}$. The effect of various side wall inclination angles on the average Nusselt number with nanoparticle volume fractions at $D a=10^{-4}, S=0.5$ and $\varpi=0^{\circ}$ can be seen in Figure $8(\mathrm{~b})$. We found that the average Nusselt number increases with the increase in $\phi$, consequently enhancing the heat transfer rate. Furthermore, the higher inclination angle of the sidewall strongly enhances the convection, which has the maximum value of average Nusselt number.
Figure 9(a) displays the variations in the average Nusselt numbers with porous layer thickness for different Darcy numbers for water-Cu at $R a=10^{6}, \phi=0.05, \varphi=$ $16.7^{\circ}$ and $\varpi=0^{\circ}$. The values of average Nusselt number clearly show that the convection heat transfer decreases systematically with an increase in porous layer thickness. The heat transfer rate is more influenced by lower Darcy numbers, whereby the maximum value of average Nusselt number occurs for higher Darcy number $D a=10^{-3}$. Figure 9(b) shows the effect of nanoparticle volume fractions on the average Nusselt number with porous layer thickness for water- $\mathrm{Cu}$ at $\mathrm{Ra}=10^{6}, \mathrm{Da}=10^{-4}, \varphi=16.7^{\circ}$ and $\varpi=$ $0^{\circ}$. The heat transfer rate tends to decrease by the increase in porous layer thickness. Significant enhancement occurs for higher concentrations of nanoparticle volume fraction $(\phi=0.2)$, which leads to the maximum value of average Nusselt number.

The effect of various inclination angle of the cavity on the average Nusselt number with nanoparticle volume fractions for water-Cu at $R a=10^{6}, D a=10^{-4}, S=0.5$ and $\varphi=16.7^{\circ}$ is shown in Figure 10(a). Similar to the previous figures, increasing the nanoparticle volume fractions is clearly enhanced the heat transfer rate due to high thermal conductivity of the nanoparticles. Furthermore, the convection heat transfer increases with the increment of the inclination angle of the cavity. Smaller inclination angle $\left(\varpi=30^{\circ}\right)$ transfers less heat which has the minimum value

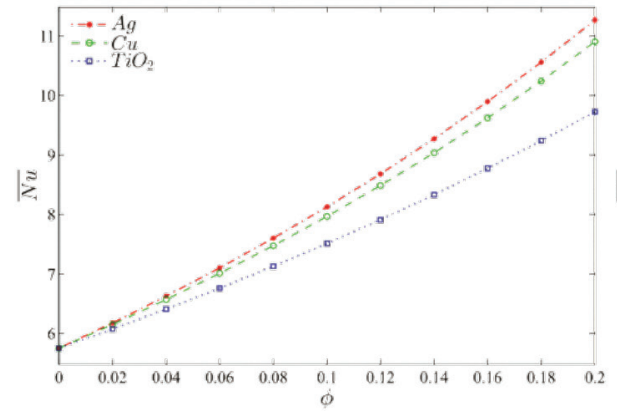

(a)

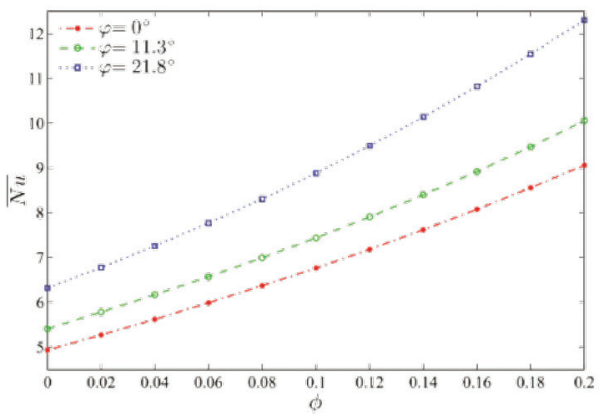

(b)

FIGURE 8. Variation of the average Nusselt number interfaces with $\phi$ for different

(a) nanoparticles, (b) $\varphi$ at $R a=10^{6}, D a=10^{-4}, S=0.5$ and $\varpi=0^{\circ}$ 


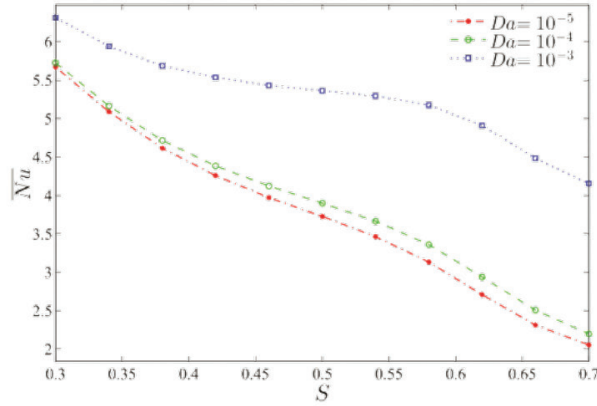

(a)

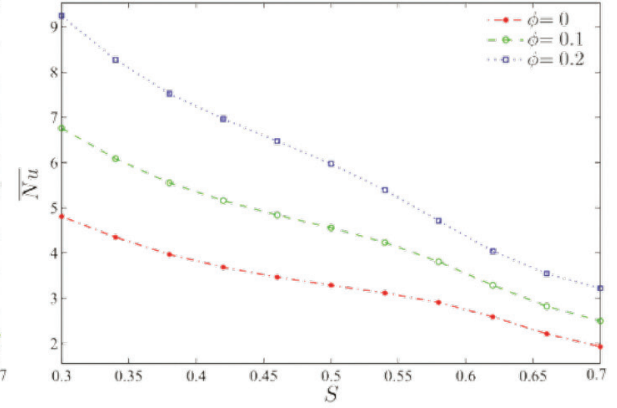

(b)

FIGURE 9. Variation of the average Nusselt number interfaces with $S$ for different (a) $D a$, (b) $\phi$ at $R a=10^{6}, \varphi=16.7^{\circ}$ and $\varpi=0^{\circ}$

of the average Nusselt number. Figure 10(b) illustrates the effect of various inclination angle of the cavity on the average Nusselt number with porous layer thickness at $R a=10^{6}, D a=10^{-4}, \phi=0.06$ and $\varphi=16.7^{\circ}$. It can be seen from the $\overline{N u}$ lines that, the convection heat transfer is clearly decreased with an increase in the porous layer thickness. As a result, we observed almost no changing in the heat transfer rate at lower inclination angle $\varpi=30^{\circ}$.

Figure 11(a) demonstrates the effect of various porous layer thickness on the average Nusselt number with inclination angle of the cavity for water- $\mathrm{Cu}$ at $\mathrm{Ra}=10^{6}, \mathrm{Da}$
$=10^{-4}, \phi=0.05$ and $\varphi=16.7^{\circ}$. It is clearly observed that, the convection heat transfer enhances with the inclination angle increment due to the variety of the flow velocity. However, the heat transfer rate decreases by increasing the porous layer thickness which leads the average Nusselt number to occur with maximum value at lower value. This is due to the fact that the thermal conductivity decreases with an increasing of the porous layer thickness. Figure 11(b) depicts the effect of various side wall inclination angle on the average Nusselt number with inclination angle of the cavity for water-Cu at $R a=10^{6}, D a=10^{-4}, \phi=0.05$

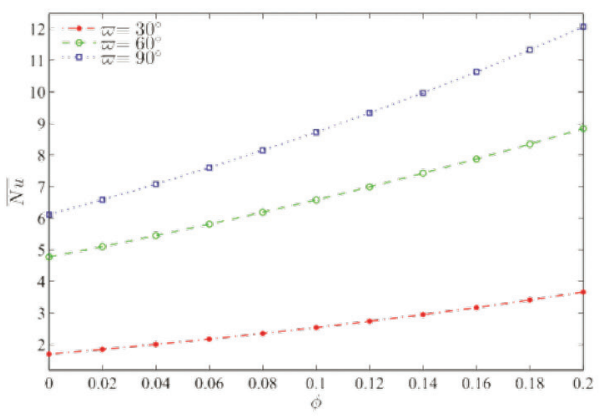

(a)

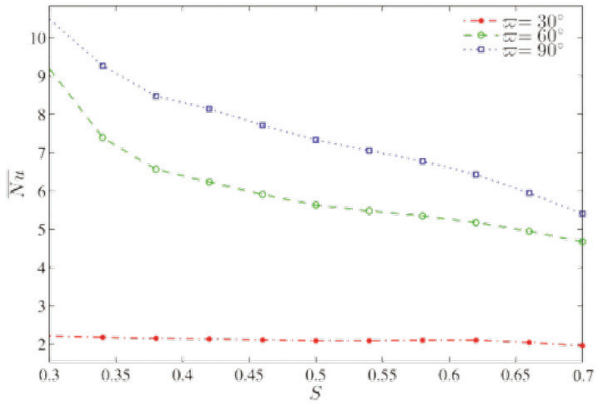

(b)

FIGURE 10. Variation of the average Nusselt number interfaces with (a) $\phi$,

(b) $S$ for different $\sigma$ at $R a=10^{6}, D a=10^{-4}$ and $\varphi=16.7^{\circ}$

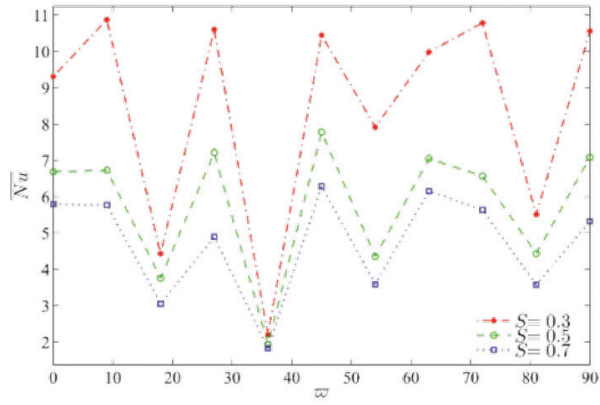

(a)

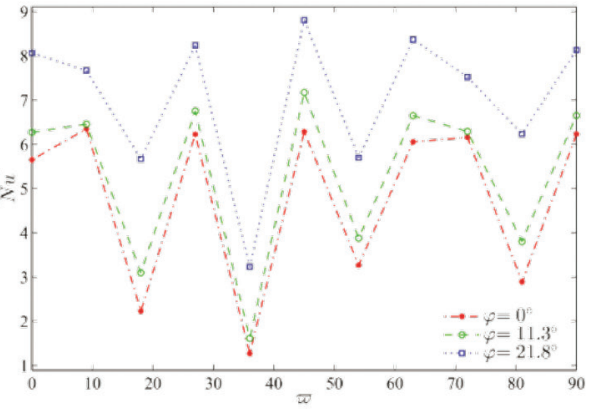

(b)

FIGURE 11. Variation of the average Nusselt number interfaces with $\varpi$ for different

(a) $S$, (b) $\varphi$ at $R a=10^{6}, D a=10^{-4}$ and $\phi=0.05$ 
and $S=0.5$. The convection heat transfer is significantly influenced by rising the inclination angle of the cavity. We noted the strong enhancement in the heat transfer rate at higher side wall inclination angle $\left(\varphi=2.18^{\circ}\right)$ which leads to the maximum value of the average Nusselt number. This is due to the fact that, more heat can be transferred within the sloping walls of the cavity.

\section{CONCLUSION}

Some important conclusions from the study are provided as follows: It is found that when the nanoparticle volume fraction is applied, the circulation intensity increases due to the increase in thermal conductivity of the nanofluid. The conduction heat transfer pushes the isotherms within the porous layer to take almost a diagonal shape, while the convection mode heat transfer forces the isotherms within the nanofluid layer to appear almost horizontal to the sloping walls. A higher nanoparticle volume fraction $(\phi=0.2)$ leads to a higher overall Nusselt number due to higher thermal conductivity. The smaller porous layer thickness $(S=0.3)$ has stronger effect on the heat transfer rate, which has the higher average Nusselt number due to lower thermal conductivity of pure fluid compared to that of nanofluid. Qualitatively, the enhanced-heat transfer situation is seen in all the three nanofluids compared to that of the base fluid but the following general result holds: $N u^{\text {water-Ag }}>N u^{\text {water-Cu}}>N u^{\text {water- } \mathrm{TiO}_{2}}$. The ramification of this important result can be seen in the context of heat removal and heat storage systems like solar energy systems and nuclear energy systems.

\section{ACKNOWLEDGEMENTS}

The work was supported by the research grants FRGS/1/2014/SG04/UKM/01/1 and DIP-2014-015.

\section{REFERENCES}

Abouali, O. \& Falahatpisheh, A. 2009. Numerical investigation of natural convection of $\mathrm{al}_{2} \mathrm{O}_{3}$ nanofluid in vertical annuli. Heat and Mass Transfer 46(1): 15-23.

Al-Nimr, M. \& Alkam, M. 1998. Unsteady non-Darcian fluid flow in parallel-plates channels partially filled with porous materials. Heat and Mass Transfer 33(4): 315-318.

Alloui, Z., Vasseur, P. \& Reggio, M. 2011. Natural convection of nanofluids in a shallow cavity heated from below. International Journal of Thermal Sciences 50(3): 393-385.

Alsabery, A., Saleh, H., Arbin, N. \& Hashim, I. 2015. Unsteady natural convection in a square cavity partially filled with porous media using a thermal non-equilibrium model. International Journal of Mathematical, Computational, Physical and Quantum Engineering 9(1): 2-7.

Beavers, G.S. \& Joseph, D.D. 1967. Boundary conditions at a naturally permeable wall. Journal of Fluid Mechanics 30(01): 197-207.

Beckermann, C., Ramadhyani, S. \& Viskanta, R. 1987. Natural convection flow and heat transfer between a fluid layer and a porous layer inside a rectangular enclosure. Journal of Heat transfer 109(2): 363-370.
Beckermann, C., Viskanta, R. \& Ramadhyani, S. 1988. Natural convection in vertical enclosures containing simultaneously fluid and porous layers. Journal of Fluid Mechanics 186: 257-284.

Bejan, A., Dincer, I., Lorente, S., Miguel, A. \& Reis, H. 2013. Porous and Complex Flow Structures in Modern Technologies. New York: Springer Science \& Business Media.

Chamkha, A.J. \& Ismael, M.A. 2014. Natural convection in differentially heated partially porous layered cavities filled with a nanofluid. Numerical Heat Transfer, Part A: Applications 65(11): 1089-1113.

Chamkha, A.J., Selimefendigil, F. \& Ismael, M.A. 2016. Mixed convection in a partially layered porous cavity with inner rotating cylinder. Numerical Heat Transfer, Part A 69: 659675.

Chen, X., Yu, P., Sui, Y., Winoto, S. \& Low, H. 2009. Natural convection in a cavity filled with porous layers on the top and bottom walls. Transport in Porous Media 78(2): 259-276.

Goyeau, B., Lhuillier, D., Gobin, D. \& Velarde, M. 2003. Momentum transport at a fluid-porous interface. International Journal of Heat and Mass Transfer 46(21): 4071-4081.

Heris, S.Z., Pour, M.B., Mahian, O. \& Wongwises, S. 2014. A comparative experimental study on the natural convection heat transfer of different metal oxide nanopowders suspended in turbine oil inside an inclined cavity. International Journal of Heat and Mass Transfer 73: 231-238.

Jahanshahi, M., Hosseinizadeh, S., Alipanah, M., Dehghani, A. \& Vakilinejad, G. 2010. Numerical simulation of free convection based on experimental measured conductivity in a square cavity using water/sio nanofluid. International Communications in Heat and Mass Transfer 37(6): 687-694.

Jiang, H., Zhang, Q. \& Shi, L. 2015. Effective thermal conductivity of carbon nanotube-based nanofluid. Journal of the Taiwan Institute of Chemical Engineers 55: 76-81.

Jou, R.Y. \& Tzeng, S.C. 2006. Numerical research of nature convective heat transfer enhancement filled with nanofluids in rectangular enclosures. International Communications in Heat and Mass Transfer 33(6): 727-736.

Kakac, S. \& Pramuanjaroenkij, A. 2009. Review of convective heat transfer enhancement with nanofluids. International Journal of Heat and Mass Transfer 52(13): 3187-3196.

Karyakin, Y.E. 1989. Transient natural convection in prismatic enclosures of arbitrary cross-section. International Journal of Heat and Mass Transfer 32(6): 1095-1103.

Khanafer, K., Vafai, K. \& Lightstone, M. 2003. Buoyancy-driven heat transfer enhancement in a two-dimensional enclosure utilizing nanofluids. International Journal of Heat and Mass Transfer 46(19): 3639-3653.

Lee, T. 1984. Computational and experimental studies of convective fluid motion and heat transfer in inclined nonrectangular enclosures. International Journal of Heat and Fluid Flow 5(1): 29-36.

Mharzi, M., Daguenet, M. \& Daoudi, S. 2000. Thermosolutal natural convection in a vertically layered fluid-porous medium heated from the side. Energy Conversion and Management 41(10): 1065-1090.

Mohamed, M.K.A., Noar, N.A.Z.M., Salleh, M.Z. \& Ishak, A. 2016. Free convection boundary layer flow on a horizontal circular cylinder in a nanofluid with viscous dissipation. Sains Malaysiana 45(2): 289-296.

Nasrin, R. \& Parvin, S. 2012. Investigation of buoyancy-driven flow and heat transfer in a trapezoidal cavity filled with 
water-cu nanofluid. International Communications in Heat and Mass Transfer 39(2): 270-274.

Nield, D.A.\& Bejan, A. 2006. Convection in Porous Media. New York: Springer Science \& Business Media.

Pop, I. \& Ingham, D.B. 2001. Convective Heat Transfer: Mathematical and Computational Modelling of Viscous Fluids and Porous Media. Cluj: Elsevier.

Poulikakos, D., Bejan, A., Selimos, B. \& Blake, K. 1986. High rayleigh number convection in a fluid overlaying a porous bed. International Journal of Heat and Fluid Flow 7(2): 109-116.

Putra, N., Roetzel, W. \& Das, S.K. 2003. Natural convection of nano-fluids. Heat and Mass Transfer 39(8-9): 775-784.

Saleh, H., Roslan, R. \& Hashim, I. 2011. Natural convection heat transfer in a nanofluid-filled trapezoidal enclosure. International Journal of Heat and Mass Transfer 54(1): 194-201.

Santra, A.K., Sen, S. \& Chakraborty, N. 2008. Study of heat transfer augmentation in a differentially heated square cavity using copper-water nanofluid. International Journal of Thermal Sciences 47(9): 1113-1122.

Sathe, S., Lin, W.Q. \& Tong, T. 1988. Natural convection in enclosures containing an insulation with a permeable fluidporous interface. International Journal of Heat and Fluid Flow 9(4): 389-395.

Sheremet, M.A., Grosan, T. \& Pop, I. 2015. Free convection in a square cavity filled with a porous medium saturated by nanofluid using Tiwari and Das' nanofluid model. Transport in Porous Media 106(3): 595-610.

Singh, A. \& Thorpe, G. 1995. Natural convection in a confined fluid overlying a porous layer-a comparison study of different models. Indian Journal of Pure and Applied Mathematics 26: 81-95.

Su, F., Ma, X. \& Lan, Z. 2011. The effect of carbon nanotubes on the physical properties of a binary nanofluid. Journal of the Taiwan Institute of Chemical Engineers 42(2): 252-257.

Tham, L. \& Nazar, R. 2012. Mixed convection flow about a solid sphere embedded in a porous medium filled with a nanofluid. Sains Malaysiana 41(12): 1643-1649.
Tiwari, R.K. \& Das, M.K. 2007. Heat transfer augmentation in a two-sided lid-driven differentially heated square cavity utilizing nanofluids. International Journal of Heat and Mass Transfer 50(9): 2002-2018.

Wang, X.Q.\& Mujumdar,A.S. 2007. Heat transfer characteristics of nanofluids: A review. International Journal of Thermal Sciences 46(1): 1-19.

A.I. Alsabery, H. Saleh \& I. Hashim*

School of Mathematical Sciences

Faculty of Science and Technology

Universiti Kebangsaan Malaysia

43600 UKM Bangi, Selangor Darul Ehsan

Malaysia

A.J. Chamkha

Department of Mechanical Engineering

Prince Mohammad Bin Fahd University

P.O. Box 1664, Al Khobar 31952

Saudi Arabia

A.J. Chamkha

Prince Sultan Endowment for Energy and Environment Prince Mohammad Bin Fahd University

Al-Khobar 31952

Saudi Arabia

B. Chanane

Department of Mathematics and Statistics

King Fahd University of Petroleum \& Minerals

Dhahran-31261

Saudi Arabia

*Corresponding author; email: ishak_h@ukm.edu.my

Received: 22 February 2016

Accepted: 1 November 2016 